\title{
Abundance, biomass and growth rates of pelagic microorganisms in a tropical coastal ecosystem
}

\author{
Petra Wallberg $^{1, *}$, Per R. Jonsson ${ }^{2}$, Ron Johnstone ${ }^{1}$ \\ ${ }^{1}$ Department of Zoology, Stockholm University, S-106 91 Stockholm, Sweden \\ ${ }^{2}$ Tjärnö Marine Biological Laboratory, S-452 96 Strömstad, Sweden
}

\begin{abstract}
In situ growth rates of ciliates and heterotrophic nanoflagellates were determined after size fractionation during rainy and dry seasons at 2 coastal stations off Zanzibar Island, Tanzania. In addition, bacterial and primary production and the biomass components in the pelagic microbial community were measured. The bacterial and primary production, and growth rates of heterotrophic nanoflagellates were significantly higher during the rainy season. For the ciliate community the growth rate between the seasons did not differ, but the number of positive growth estimates increased by a factor of 5 in the rainy seasons compared with the dry seasons. Further, the diversity of ciliates increased with the amount of rain, and the size distribution indicated a shift towards a community with larger species. Data obtained from these experiments are summarised in a carbon budget for each season. Carbon budgets indicate that the carbon flow through the heterotrophic microbial food web was approximately 3 times higher during the rainy season compared with the dry season. However, due to the relatively lower production of larger diatoms, heterotrophic microplankton may be relatively more important as a carbon source for higher trophic levels, such as copepods, during the dry season.
\end{abstract}

KEY WORDS: Ciliates - Microbial food web - Growth rates Carbon budget - East Africa

\section{INTRODUCTION}

The composition and the production pattern of the plankton community are likely to influence the foodweb structure of larger predators, nutrient cycling and the sinking flux. In general, stratified and oligotrophic pelagic ecosystems are to a higher extent based on a microbial food web (including bacteria, protozoa and autotrophic pico- and nanophytoplankton) in contrast to turbulent and nutrient-rich environments where a diatom-based food chain develops (Cushing 1989, Legendre \& Rassoulzadegan 1995). However, the relative dominance of a diatom-based food chain and the microbial food web varies in both space and time. For instance, microbial-web dominance usually increases from coastal areas to offshore (Kiørboe et al. 1990), and a bloom of larger phytoplankton is generally closely followed by the development of a microbial food web (Sorokin 1981).

\footnotetext{
•E-mail: petra.wallberg@itm.su.se
}

The dominance of a microbial food web in oligotrophic waters may partly be explained by the strong competition for nutrients that will select for small cells with large area-to-volume ratios. Therefore, nanosized autotrophic flagellates and pico-sized cyanobacteria are usually the major contributors to the ocean photosynthesis (Waterbury et al. 1979, Li et al. 1983). Heterotrophic bacteria growing on e.g. exudates from autotrophs may also successfully compete for nutrients in oligotrophic waters. For instance, in studies conducted in oceanic environments the biomass of heterotrophic bacteria has been reported to even exceed autotrophic biomass (Fuhrman et al. 1989, Cho \& Azam 1990, Roman et al. 1995). On a global scale bacterial abundance shows a low regional and seasonal variation (Ducklow \& Carlson 1992) which indicates a strong control of the bacterial community (Fenchel 1982). This control is fundamental for the coexistence of small and larger cells and can be due to substrate limitation or predation or the combined effect of both (Pengerud et al. 1987). Important predators of the very small cells at the food-web base are heterotrophic fla- 
gellates and ciliates (Andersen \& Fenchel 1985, Sherr et al. 1989), which form a link to larger zooplankton, e.g. copepods (Jonsson \& Tiselius 1990).

The generally nutrient-limited situations in tropical and subtropical areas suggest that the transport of carbon from bacteria to higher trophic levels could be a significant pathway in these ecosystems. For instance, based on high C:chlorophyll ratios in faecal pellets Roman et al. (1995) reported that zooplankton $(>200 \mu \mathrm{m})$ in the Sargasso Sea mainly consumed heterotrophic carbon sources. Intense research over the past decades has considerably advanced our knowledge about pelagic ecosystems in temperate waters. From tropical ecosystems there are several studies on different components of the microbial food web (e.g. Gilron \& Lynn 1989, Torréton et al. 1989, Stoecker et al. 1996), but limited data on the dynamics within microbial plankton communities (Roman et al. 1995, Reckermann \& Veldhuis 1997)

Although the seasonal variability in tropical and subtropical oceans is not as pronounced as in temperate regions, the plankton community may exhibit a seasonal cycle. In the open seas the seasonality can be related to input of nutrients due to changes in the depth of the mixed layer (Roman et al. 1995), and in nearshore areas to nutrient input from land, depending on the seasonality in rainfall (Gallegos et al. 1992, Hama \& Handa 1994). The purpose of this study is to describe the food-web structure and to quantify the carbon fluxes within the microbial community in a coastal ecosystem off the coast of Zanzibar (Unguja) Island, Tanzania, and test for differences between the rainy and the dry seasons.

\section{MATERIAL AND METHODS}

Sampling site. Zanzibar Island is situated off the Tanzanian coast $\left(5^{\circ} 40^{\prime}-6^{\circ} 30^{\prime} \mathrm{S}, 39^{\circ} 10^{\prime}-39^{\circ} 35^{\prime} \mathrm{E}\right)$. The rainy seasons occur during March to May and October to November. The north-east monsoon blows from December to April and is characterised by higher air temperatures $\left(>30^{\circ} \mathrm{C}\right)$, lower wind speeds and calmer seas. The south-east monsoon blows from June to October and is by contrast characterised by cooler air temperatures $\left(\sim 25^{\circ} \mathrm{C}\right)$, higher wind speeds and rougher seas. The tidal amplitude varies between 0.9 and $4.6 \mathrm{~m}$. Seawater was collected at 2 stations off Zanzibar town (Fig. 1). In this area there is no freshwater supply from rivers but untreated sewage water is discharged into the coastal water. Each station was sampled twice on each sampling occasion in August 1995 and 1996 (dry season), and April 1996 and 1997 (rainy season) at $2.5 \mathrm{~m}$ depth. The depths at the sampling stations were 15 and $25 \mathrm{~m}$, respectively. In order

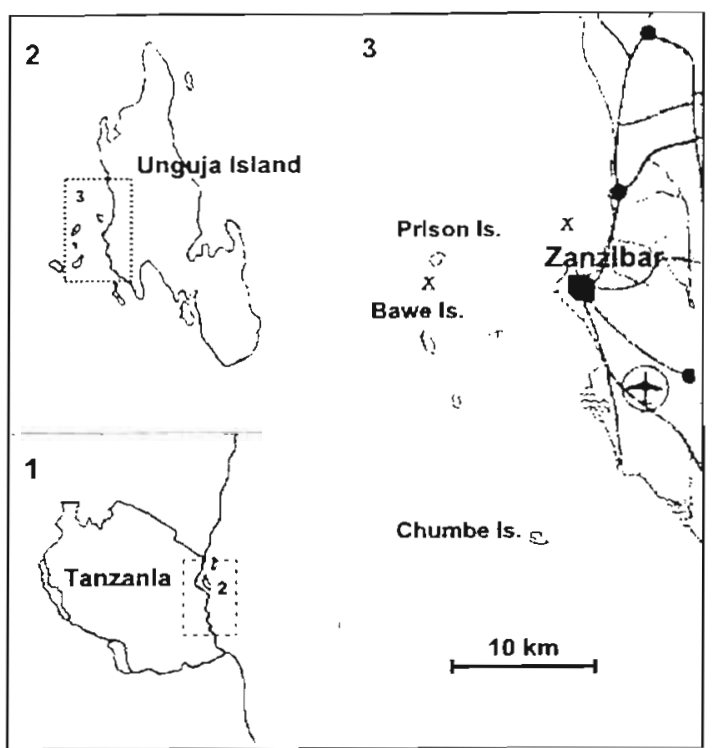

Fig. 1. Tanzania and Zanzibar Island. The sampling stations, situated outside Zanzibar Town, are marked with an X

to get the largest contrast between the stations, samples from the nearshore station were always collected at low tide and samples from the offshore station at high tide.

Nutrient analysis. For the determination of the concentration of dissolved nutrients duplicate samples of $50 \mathrm{ml}$ of seawater were filtered through a $0.45 \mu \mathrm{m}$ $25 \mathrm{~mm}$ Millex-HA filter that had been acid washed with $10 \% \mathrm{HCl}$ and thoroughly rinsed with Milli-Q water. Fifty ml of unfiltered seawater was collected for estimation of total nitrogen and phosphorus concentrations. Except for the analysis of ammonium, samples were stored frozen until analysis using an autoanalyser (Lachat Quick Chem 800). For measurements of ammonium concentrations, triplicate samples were preserved with phenol and analyzed directly after sampling according to Parsons et al. (1989) using a Shimadzu - 1201 spectrophotometer.

Dissolved organic carbon (DOC). Duplicate $7 \mathrm{ml}$ samples of seawater were filtered through a $0.45 \mu \mathrm{m}$ $25 \mathrm{~mm}$ Millex-HA filter that had been acid washed with $10 \% \mathrm{HCl}$ and thoroughly rinsed with Milli-Q water. Samples were preserved with $100 \mu \mathrm{l} 1 \mathrm{M} \mathrm{HCl}$. The samples were stored at $4{ }^{\circ} \mathrm{C}$ until analyzed with a Shimadzu TOC 5000.

Particulate organic carbon (POC). Duplicate samples $(500 \mathrm{ml})$ were filtered onto a precombusted $\left(450^{\circ} \mathrm{C}\right.$ for $3 \mathrm{~h}$ ) GF/F $25 \mathrm{~mm}$ glass fibre filter (Whatman). Filters were then dried at $40^{\circ} \mathrm{C}$ overnight and stored frozen until analyzed with a Carlo Erba 1106 Elemental Analyzer. The carbon content of non-filtered blank filters was subtracted from the filter samples. 
Picoplankton. Twenty ml of seawater was preserved with formalin to a final concentration of $2.5 \%$. For enumeration and measurement of picocyanobacteria, $10 \mathrm{ml}$ of seawater was collected on a $0.6 \mu \mathrm{m} 25 \mathrm{~mm}$ polycarbonate filter (Poretics). For enumeration of heterotrophic bacteria, 1 or $2 \mathrm{ml}$ of seawater was stained with DAPI (Porter \& Feig 1980) and filtered through $0.2 \mu \mathrm{m} 25 \mathrm{~mm}$ black polycarbonate filters (Poretics). Samples were counted in an epifluorescence microscope at $1200 \times$ magnification, using UV excitation light. At least 300 cells per filter were counted.

Abundances and growth rates of ciliates and heterotrophic nanoflagellates. To estimate the abundance and growth rates of heterotrophic nanoflagellates (HNF) seawater was filtered by gravity through a $5 \mu \mathrm{m}$ polycarbonate filter (Poretics) and triplicate samples were incubated for $20 \mathrm{~h}$ in a water bath at ambient water temperature. Incident light was screened to $75 \%$ $I_{0}$ by a neutral filter. At the start and at the end of the experiment, $10 \mathrm{ml}$ of live samples was stained with proflavine, fixed with ice-cold glutaraldehyde, and filtered onto $0.8 \mu \mathrm{m} 25 \mathrm{~mm}$ black polycarbonate filters (Poretics) (Haas 1982). The filters were stored frozen and enumerated within $24 \mathrm{~h}$ in an epifluorescence microscope.

Abundance and growth rates of ciliates were measured in size fractionated water samples. The seawater was filtered with reversed filtration through $200 \mu \mathrm{m}$ and $50 \mu \mathrm{m}$ sieves to remove larger predators. Triplicate samples were incubated for $24 \mathrm{~h}$ in 2.51 polycarbonate bottles. Triplicate $1 \mathrm{l}$ samples from each fraction were preserved in $1 \%$ acid Lugol's solution initially and at the end of each experiment. After $24 \mathrm{~h}$, the fixed samples were concentrated on a $10 \mu \mathrm{m}$ mesh net and rinsed into $50 \mathrm{ml}$ containers. This method is quantitative according to Tiselius (1989). After overnight sedimentation half of the sedimentation chamber or at least 400 cells (not including the autotrophic Mesodinium rubra) were counted in an inverted microscope at $250 \times$ magnification. Identification of the ciliates to family or genus was based on Montagnes \& Lynn (1991) and Marshall (1969).

Population growth rates $(\mu)$ for HNF and ciliates were calculated from the changes in abundance, assuming exponential growth: $\mu=\ln [N(t) / N(0)] / t$, where $N(0)$ and $N(t)$ are the mean number of cells at the start and at the end of the experiment, and $t$ is the duration of the experiment. Ingestion rate was calculated from the growth rate assuming complete heterotrophy and a carbon gross growth efficiency of $30 \%$ (e.g. Fenchel \& Finlay 1983, Andersen \& Sørensen 1986, Wallberg \& Andersson unpubl.).

Biomass estimations. The size of different taxonomic groups was measured under the microscope using an ocular micrometer (eukaryotic taxonomic groups $\geq 50$ cells sample $e^{-1}$, bacteria $\geq 300$ cells sample sa $^{-1}$. The carbon content of bacteria was calculated from data in Simon \& Azam (1989) and pico- and nanoplankton according to Verity et al. (1992):

Heterotrophic bacteria:

$$
\log _{10} C=-1.036+0.599(\log B V)
$$

Pico- and nanoplankton:

$$
\log _{10} C=-0.363+0.863(\log B V)
$$

$B V$ is biovolume in $\mu^{3}$ cell $^{-1}$ and the carbon content $(C)$ is given in pg C cell ${ }^{-1}$. The carbon content of ciliates was calculated using a conversion factor of $0.19 \mathrm{pg}$ C $\mu \mathrm{m}^{-3}$ (Putt \& Stoecker 1989).

Mixotrophic ciliates. To get an estimate of the percentage of mixotrophic ciliates, 1 seawater sample $(225 \mathrm{ml})$ from each station was preserved with $20 \%$ formalin buffered with hexamethylenetetramine to a final concentration of $2 \%$ (Stoecker et al. 1989). $100 \mathrm{ml}$ was concentrated overnight in a settling chamber and ciliates in half of the chamber were examined with blue excitation light in an epifluorescence microscope. The samples collected in August 1995 were lost.

Other microplankton components. One litre of seawater was preserved with $1 \%$ acid Lugol's solution and thereafter treated as the samples for the estimation of ciliate growth rates. In this case the dominant phytoplankton genera were identified and for the abundance of dinoflagellates 2 diagonals of the chamber $\left(44.6 \mathrm{~mm}^{2}\right)$ were scanned at $250 \times$ magnification.

Chlorophyll a. The concentration of chlorophyll a was determined according to Parsons et al. (1989). Duplicate samples of 21 of seawater were filtered onto $0.65 \mu \mathrm{m} 47 \mathrm{~mm}$ Millipore membrane filters, extracted in $90 \%$ acetone overnight and measured using a Shimadzu - 1201 spectrophotometer.

Primary production. Thirty $\mathrm{ml}$ of seawater was gently poured into polycarbonate bottles (Nalgene) and $5 \mu \mathrm{Ci}$ of sodium $\left({ }^{14} \mathrm{C}\right)$ bicarbonate $\left(0.1 \mathrm{mCi} \mathrm{mmol}^{-1}\right)$ was added. Triplicate light and dark bottles were incubated from noon until sunset in a water bath at ambient temperature. The incident light was screened to $75 \% I_{0}$ by a neutral filter. Subsamples of $5 \mathrm{ml}$ were added to scintillation vials, acidified with $300 \mu \mathrm{l}$ of $6 \mathrm{M} \mathrm{HCl}$ and thereafter bubbled for $40 \mathrm{~min}$. Fifteen $\mathrm{ml}$ of scintillation fluid Optiphase Hisafe 3 (Wallac) was added and the samples were counted in a Beckman LS1801 scintillation counter using a quench correcting program. Dissolved inorganic carbon concentration in the water was calculated from $\mathrm{pH}$ and salinity (Parsons et al. 1989)

Bacterial production. The bacterial production was determined using the tritiated thymidine method as modified by Smith \& Azam (1992). Tritiated thymidine $\left(46 \mathrm{Ci} \mathrm{mmol}^{-1}\right)$ was added to a final concentration of $20 \mathrm{nM}$, which was at the level of saturation. The con- 
version factor for the number of cells produced per mol thymidine incorporated was estimated according to Kirchman \& Ducklow (1993) and determined to be $1.3 \times 10^{18}$. The production in terms of carbon biomass ( $\mu \mathrm{g} \mathrm{Cl}^{-1}$ ) was calculated by multiplying the number of cells produced by the average cell carbon content. The bacterial production was assumed to be constant over a $24 \mathrm{~h}$ period and carbon gross growth efficiency to be $50 \%$ (Ducklow \& Carlson 1992).

Statistical analysis. As the experimental set up was not designed to test for differences between the stations, these data were pooled. The differences of biological and chemical parameters between the seasons were statistically tested using a 1-factor analysis of variance (ANOVA). Homogeneity of the variances was checked for with Cochran's test (Winer et al. 1991). An $\alpha$ of 0.05 was used in all statistical tests.

\section{RESULTS}

\section{Hydrography and nutrients}

The temperature in the water column varied between 25 and $29^{\circ} \mathrm{C}$, with the lowest measurements recorded during the dry seasons (August; Table 1). The variation within the seasons was $\leq 1^{\circ} \mathrm{C}$. The rainfall during the sampling periods was $\geq 4$ times higher dur-

Table 1. Average values of environmental variables during the sampling periods

\begin{tabular}{|lccc|}
\hline $\begin{array}{l}\text { Month and } \\
\text { year }\end{array}$ & $\begin{array}{c}\text { Temp } \\
\left({ }^{\circ} \mathrm{C}\right)\end{array}$ & $\begin{array}{c}\text { Rainfall } \\
\left(\mathrm{mm} \mathrm{mo}^{-1}\right)\end{array}$ & $\mathrm{pH}$ \\
\hline August 1995 & 25 & 57 & 8.1 \\
August 1996 & 26 & 11 & 8.3 \\
April 1996 & 29 & 259 & 8.2 \\
April 1997 & 28 & 369 & 8.1 \\
\hline
\end{tabular}

Table 2. Average values with standard deviations of nutrient and chlorophyll a concentrations during the rainy and dry seasons, respectively. All values are given in $\mu \mathrm{g}^{-1}$

\begin{tabular}{|lcc|}
\hline Parameter & Rainy season & Dry season \\
\hline Phosphate & $3.7 \pm 2.7$ & $3.8 \pm 0.3$ \\
Nitrate & $2.1 \pm 1.5$ & $2.0 \pm 1.9$ \\
Ammonia & $5.9 \pm 7.7$ & $2.5 \pm 0.6$ \\
Silica & $38.0 \pm 16.3$ & $73.2 \pm 18.5$ \\
Total N & $100.0 \pm 15.0$ & $83.0 \pm 8.2$ \\
Total P & $11.2 \pm 3.1$ & $9.2 \pm 0.3$ \\
DOC & $1500 \pm 200$ & $1400 \pm 300$ \\
POC & $274 \pm 68$ & $133 \pm 54$ \\
Chlorophyll a & $1.2 \pm 0.7$ & $1.0 \pm 1.2$ \\
\hline
\end{tabular}

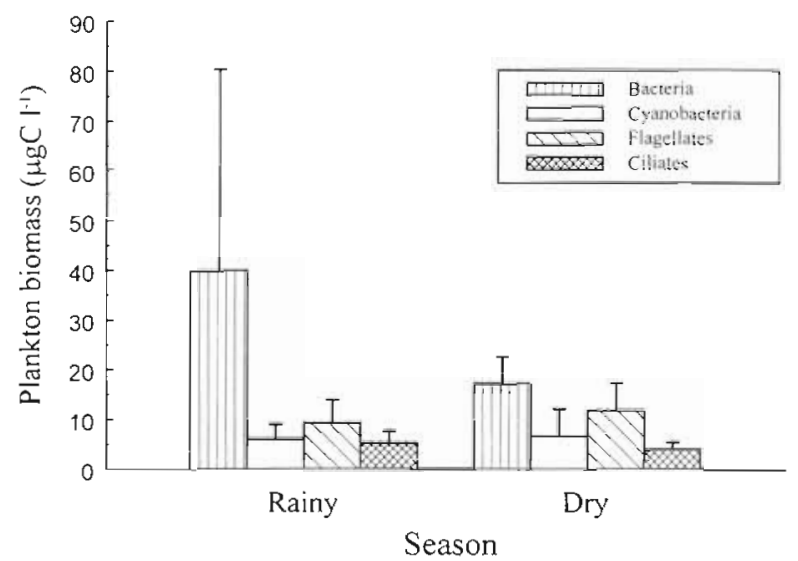

Fig. 2. Biomasses of heterotrophic microorganisms and picocyanobacteria during the sampling seasons. Error bars show the standard deviation

ing the rainy seasons (April) than during the dry seasons (Directorate of Meteorology, Zanzibar). Although the highest concentrations of ammonium and phosphorus were measured during the rainy seasons, only silica was significantly different $(\mathrm{p}=0.002$; Table 2$)$, with lower values during the rainy compared with the dry seasons. In contrast, the concentration of total nitrogen as well as POC were significantly higher during the rainy seasons (total $\mathrm{N}, \mathrm{p}=0.035$; POC, $\mathrm{p}=0.001$ ). The concentration of total phosphorus did not significantly differ between the seasons ( $p=0.2)$, although the highest concentrations were measured during the rainy seasons.

\section{Plankton biomass}

Changes in the nutrient concentration in the water may translate into changes in the biomass at different trophic levels. In this study the abundance and biomass of heterotrophic bacteria, nanoflagellates and ciliates did not differ between the seasons (Fig. 2). The highest abundances of heterotrophic bacteria was measured during the rainy season in 1996 with 3.6 to $4.6 \times 10^{9}$ cells I $^{-1}$ at the nearshore station; this coincided with relatively higher ammonium concentrations. In contrast, for the picocyanobacteria the highest recorded values occurred during the dry season in 1995 with 1.5 to $1.6 \times 10^{8}$ cells $^{-1}$, and this coincided with the highest abundances of HNF (5.6 to $5.8 \times 10^{5}$ cells $\mathrm{l}^{-1}$ ). An analysis of the correlation between the abundances of cyanobacteria and HNF gave a coefficient of 0.65 (Spearman rank correlation, $\mathrm{p}=0.006$; Fig. 3). If the outlier (i.e. the point to the lower right of the major cluster) is excluded, this correlation increases to 0.78 (Spearman rank correlation, $\mathrm{p}=$ 

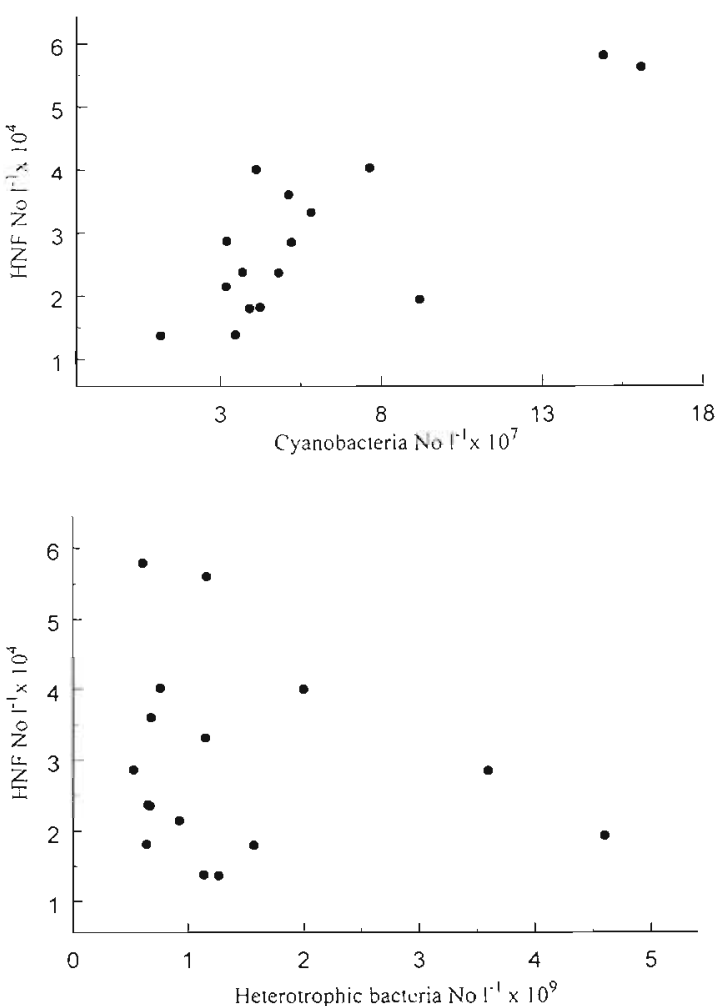

Fig. 3. Correlations between the abundances of heterotrophic nanoflagellates (HNF) and picocyanobacteria, and between HNF and heterotrophic bacteria

$0.0008)$. The corresponding correlation coefficient for the abundance of bacteria and HNF was 0.03 (Spearman rank correlation, $\mathrm{p}=0.4$; Fig. 3 ).

The most dominant groups of ciliates belonged to Strombidiidae (Laboea, Strombidium and Tontonia) and to the suborders Strobilidina and Tintinnina. The highest abundance of ciliates occurred during the rainy season in 1996 with 5700 cells $l^{-1}$, but similar values were also obtained during the dry season (e.g. 4200 cells $^{-1}$ in 1995). Chloroplast containing ciliates (excluding Mesodinium rubra) constituted on average $31 \%$ (range 19 to $46 \%$ ) of the total ciliate community and mainly belonged to the family Strombidiidae. Abundances of tintinnids varied between 37 and 285 cells $~^{-1}$, with the highest values occurring during the rainy seasons. Abundant tintinnid species included Tintinnopsis spp., Cordonellopsis ecaudata, C. Contracta, Protorhabdonella curta, Rhabdonella brandti, $R$. hebe, Epiplocyloides brandti, Amphorides minor, A. quadrilineata, Amphorellopsis acuta, Dadayiella ganymedes, Eutintinnus spp. and Salpingella spp. Although the abundance of ciliates did not significantly differ between the seasons, the size distribution indicated a shift towards a community with larger species as the level of rainfall increased. During the rainy

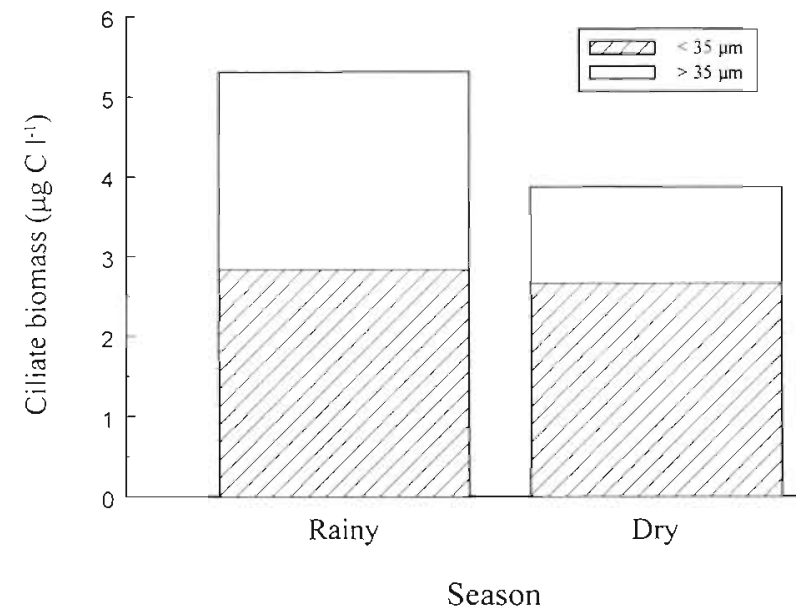

Fig. 4. Size distribution of ciliates during the rainy and dry seasons

seasons ciliates in the size range $>35 \mu \mathrm{m}$ constituted $50 \%$ of the biomass whilst the corresponding value during the dry seasons was $30 \%$ (Fig. 4). Also, the diversity showed a tendency to increase with the amount of rainfall (Fig. 5).

The abundance of dinoflagellates varied between 1 and $3 \times 10^{3}$ cells $^{-1}$ and was dominated by the genera Protoperidinium, Gyrodinium, Gymnodinium and Ceratium. The microphytoplankton was mainly dominated by diatoms such as Chaetoceros spp., Rhizosolenia

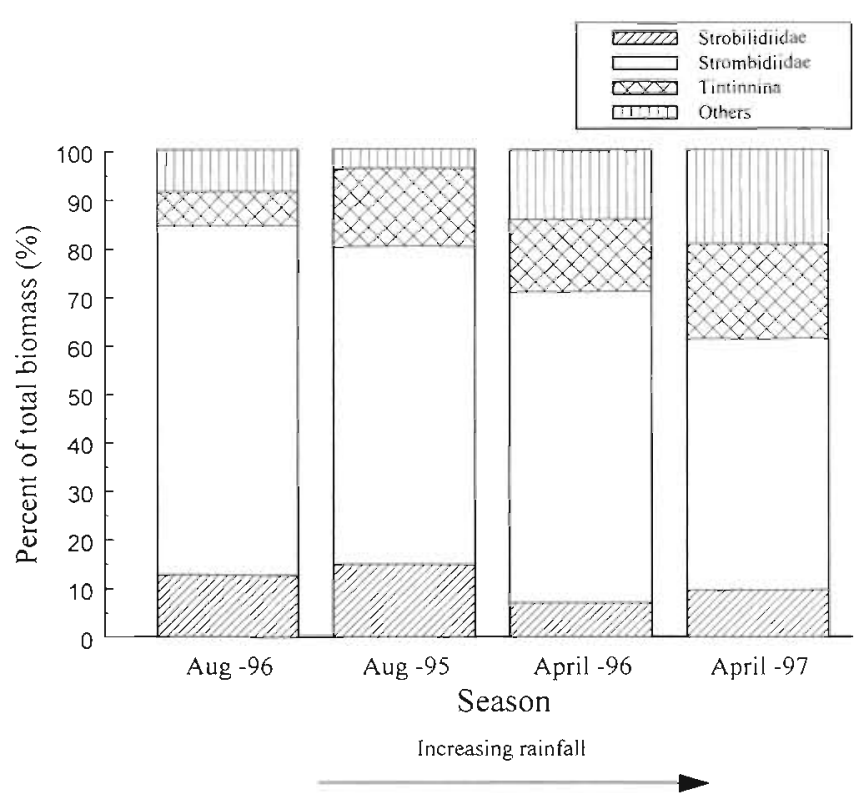

Fig. 5. Composition of the ciliate community correlated to the amount of rainfall. The sampling seasons are ordered according to an increasing amount of rainfall towards the right in the figure 
spp., Hemialus spp., Bacteriastum furcatum, Pleurosigma spp., Thalassionema nitzschioides, Thalassionema frauenfeldii, and Guinardia spp. Blooms of the filamentous cyanobacteria Trichodesmium spp. occurred in April, a phenomenon previously observed at this time of the year (Lugomela \& Semesi 1996 and references therein). The variation in biomass of autotrophic plankton was estimated with chlorophyll $a$ and did not significantly differ between the seasons ( $\mathrm{p}=$ 0.7 ; Table 2).

\section{Plankton production}

Variations in nutrient concentration may influence the growth rate of autotrophs and heterotrophic bacteria, with effects extending to higher trophic levels. Significantly higher production rates were obtained during the rainy seasons both for the primary $(p=0.004)$ and the bacterial production ( $p=0.031$; Fig. 6$)$. The primary production was on average almost 6 times and the bacterial production 7 times higher during the rainy seasons compared with the dry seasons. The higher primary production rates were also reflected by the significantly lower concentrations of silica during the rainy season.

For HNF the growth rate was significantly higher during the rainy seasons $(p=0.006)$. The specific growth rates varied between 0.0 and $0.6 \mathrm{~d}^{-1}$ (average $0.3 \mathrm{~d}^{-1}$ ) during the dry seasons and between 0.2 and $2.5 \mathrm{~d}^{-1}$ (average $1.2 \mathrm{~d}^{-1}$ ) during the rainy seasons. Thus, the highest growth rates of HNF did not coincide with the highest abundances. In contrast to the growth rates of HNF, the growth rates of ciliates did not differ between the seasons; however, the number of positive estimates of growth rates was considerably fewer dur-

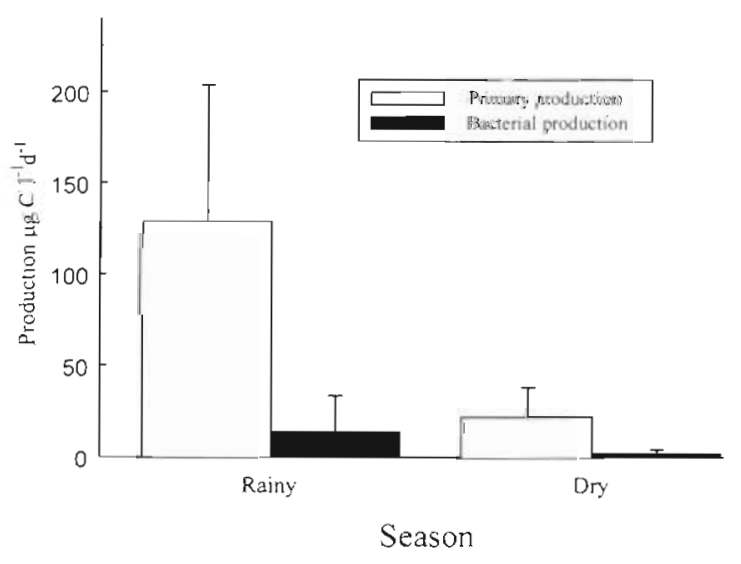

Fig. 6. Average values of the primary and bacterial production during the rainy and dry seasons. Error bars shows the standard deviation

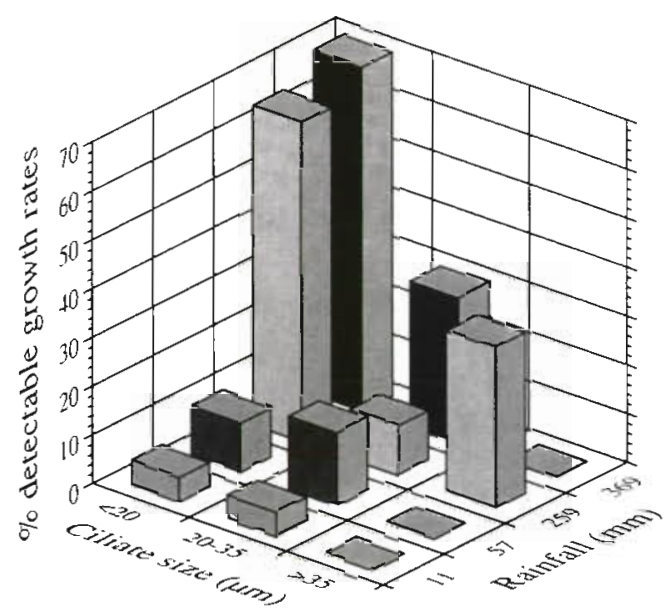

Fig. 7. Percentage of ciliate taxa (Strobilidiidae spp., Tintinnina spp., Strombidiidae spp., Scuticociliatida, Prostomatida, Monodinium spp.), grouped in 3 different size classes $(<20$, 20-35 and $>35 \mu \mathrm{m})$, showing detectable growth rates correlated with the amount of rainfall

ing the dry seasons compared to the rainy seasons (Fig. 7). For instance, no positive growth rates were obtained at the offshore station during the dry seasons. With increasing rainfall an increasing number of incubations resulted in positive growth rates, in particular for the larger ciliates. A bloom of the ciliate Laboea sp. occurred on 1 sampling occasion during the rainy season in 1996 at the nearshore station, which coincided with the highest estimated growth rates for ciliates and HNF, and the highest abundance and production of heterotrophic bacteria. On this occasion the only positive growth rates for ciliates within the taxa Tintinnina (Favella azorica), Strobilidina and Strombididae $>35 \mu \mathrm{m}$ were obtained (Table 3 ).

Table 3. Summary of data for the range of specific growth rates for different taxa and size classes of ciliates obtained in this study. Average values are given within parentheses

\begin{tabular}{|lcc|}
\hline & $\begin{array}{c}\text { Cell volume } \\
\left(\mu \mathrm{m}^{3}\right)\end{array}$ & $\begin{array}{c}\text { Specific growth rate } \\
\left(\mathrm{d}^{-1}\right)\end{array}$ \\
\hline Strobilidiidae & 2600 & $0.1-1.8(1.0)$ \\
& 11500 & $0.7-1.6(1.0)$ \\
Strombidiidae & 33500 & 0.4 \\
& 2600 & $0.2-1.5(0.7)$ \\
Tintinnina & 11500 & $0.5-1.1(0.8)$ \\
Scuticociliatida & 13100 & 0.4 \\
Prostomatida & 41900 & $0.7-1.4(1.1)$ \\
Monodinium spp. & 2600 & $0.4-2.5(1.1)$ \\
& 2600 & $0.5-1.5(0.9)$ \\
& 1800 & $0.3-0.8(0.5)$ \\
\hline
\end{tabular}




\section{DISCUSSION}

\section{Control of the plankton community}

In tropical and subtropical nearshore areas variations within the plankton community can be related to input of nutrients from land, depending on the seasonality in rainfall (Gallegos et al. 1992, Hama \& Handa 1994). In this study the concentrations of dissolved inorganic nutrients, apart from silica, were not significantly different between the 2 seasons. This may reflect that the turnover of nutrients was rapid since concentrations of total nitrogen and POC were twice as high during the rainy season. Further, the significantly lower concentration of silica coincided with a higher primary production. For heterotrophic microorganisms the difference between the studied seasons mainly occurred as an increase in growth rates rather than in abundance and biomass. This indicates that there was a tight coupling between different components of the microbial food web. In a modelling approach to assess the control of the abundance of heterotrophic bacteria (Sanders et al. 1992) and HNF (Gasol 1994), it was concluded that these communities are mainly controlled by resource limitation in oligotrophic environments and by predation in nutrient-rich systems. The weak correlation between heterotrophic bacteria and HNF in this study suggests that the bacterial abundance was controlled by substrate availability, and that HNF was also dependent on food sources other than heterotrophic bacteria. This latter hypothesis is supported by the relatively high correlation between the abundances of HNF and cyanobacteria in comparison with the lack of correlation between the abundances of HNF and heterotrophic bacteria.

For ciliates the threshold concentration for survival ranges between 10 and $100 \mu \mathrm{g} \mathrm{Cl}^{-1}$, which is near or above average typical prey biomass levels in the sea (Montagnes 1996). This indicates that the abundance of ciliates is mainly controlled by the availability of prey. However, data from Danish coastal waters indicate that the ciliate community can also be predator controlled (Nielsen \& Kiørboe 1991). It is possible that this reflects that food generally limits ciliate abundance but that top-down control increases in importance as a regulating factor in more nutrient-enriched systems.

\section{Control of ciliate growth rate}

Estimated growth rates for ciliates were within the range reported from other areas (Gilron \& Lynn 1989, Pierce \& Turner 1992), but, in contrast to other groups, growth rate for ciliates did not differ between the sea- sons. In laboratory cultures it has been demonstrated that when the food is not limiting, ciliate growth rates are closely correlated with cell size (Fenchel 1968, Finlay 1977) and temperature (Finlay 1977, Verity 1985). Comparison of in situ ciliate growth rates with growth models derived from cell size and ambient temperature could therefore indicate the degree to which the growth of natural ciliate populations may be limited by food availability. Montagnes (1996) compared laboratory-derived data on the growth rates of species of Strobilidium and Strombidium and values obtained from predictive formulas. The predictive equation suggested by Müller \& Geller (1993) was found to agree best with observed growth rates. This equation was therefore used on data from this study to compare the observed and predicted growth rates for Strobilidium spp. with the assumption that the $\mu_{\max }$ of these species show a similar functional dependence on size and temperature. The formula used was:

$$
\ln \mu_{\max }=1.52 \ln T-0.27 \ln V-1.44
$$

where $\mu_{\max }$ is the maximum growth rate, $\mathrm{d}^{-1} ; T$ is temperature, ${ }^{\circ} \mathrm{C}$; and $V$ is ciliate cell volume, $\mu \mathrm{m}^{3}$. All the predicted values were higher than the present estimates by a factor of 1.6 to 3.5 (Table 4). When testing the equation by Müller \& Geller (1993), Montagnes (1996) found that the main source of over-prediction of growth rate was related to temperatures $>20^{\circ} \mathrm{C}$, which may explain some of the differences between the predicted and the estimated $\mu_{\max }$. The largest difference between the predicted and the estimated $\mu_{\max }$ occurred for the smallest cells. In fact, estimated $\mu_{\max }$ values did not vary between the size groups. Differences between the size classes were more reflected by the fact that only the smaller-sized ciliate group showed positive growth rates during the most nutrientconstrained situations, i.e. the dry seasons and at the offshore station.

The increase in the number of positive growth rates with increasing rainfall may reflect changes in production, as well as composition, of the food sources. Further, methodological problems for estimation of proto-

Table 4. Predicted growth rate according to Müller \& Geller (1993), and the in situ estimated growth rate for Strobilidium spp. of 2 different cell volumes at $25^{\circ} \mathrm{C}$ (dry season) and $29^{\circ} \mathrm{C}$ (rainy season)

\begin{tabular}{lccc}
$\begin{array}{l}\text { Cell volume } \\
\left(\mu \mathrm{m}^{3}\right)\end{array}$ & $\begin{array}{c}\text { Temperature } \\
\left({ }^{\circ} \mathrm{C}\right)\end{array}$ & $\begin{array}{c}\text { Predicted } \\
\left(\mathrm{d}^{-1}\right)\end{array}$ & $\begin{array}{c}\mu_{\max } \\
\left(\mathrm{d}^{-1}\right)\end{array}$ \\
\hline 2600 & 25 & 3.8 & 1.1 \\
2600 & 29 & 4.7 & 1.8 \\
11500 & 25 & 2.5 & 1.6 \\
11500 & 29 & 3.7 & 1.2
\end{tabular}


zoan growth rates must be considered. For instance, the fractionation method assumes that mortality is solely caused by larger predators that are removed by filtration. Nielsen \& Kiørboe (1991) suggested that similarly sized predators such as heterotrophic dinoflagellates, which feed on smaller ciliates, will cause an underestimate of the growth rate of small ciliates relative to larger ciliates. Consequently, growth rates of ciliates, as well as those of HNF, calculated from in situ incubations can therefore, at best, be considered as conservative. However, the 5-fold increase in the number of positive growth rates and the higher number of positive estimates for the ciliates in the larger size group during the rainy seasons indicate that the ciliate community is controlled by food rather than by temperature or predators. This conclusion is also supported by the observation that the shift in the size distribution towards a community with larger ciliates coincided with an increase in the production of both heterotrophic and autotrophic plankton.
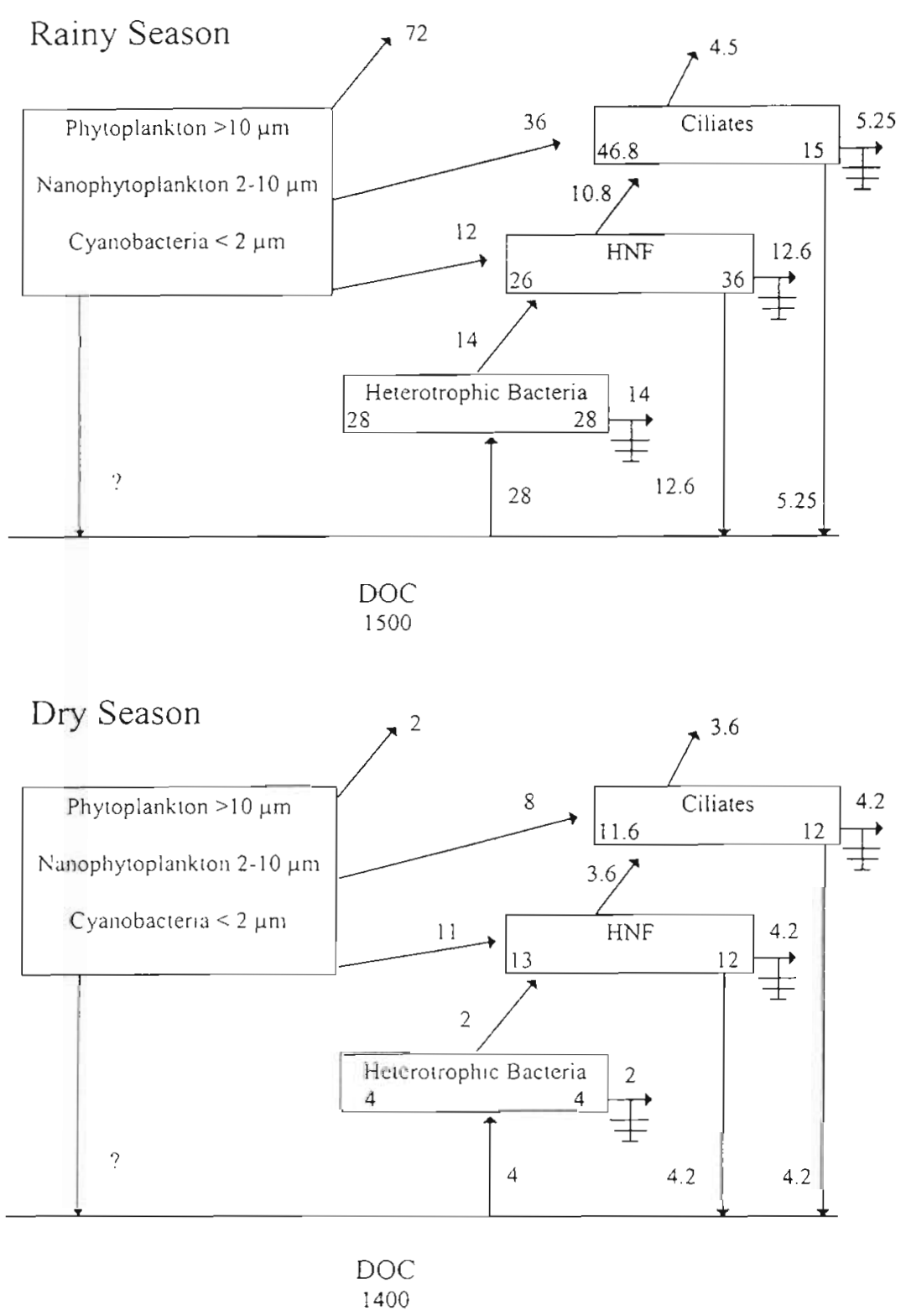

Fig. 8. Budgets for the flow of carbon through the microbial food web during the rainy and dry seasons investigated in the present study. Inward-and outwardgoing arrows represent consumption, production and respiration $\left(\mu \mathrm{g} \mathrm{Cl}^{-1} \mathrm{~d}^{-1}\right)$. In the boxes the number to the right represents the carbon demand estimated from the obtained production rates, and the number to the left represents the net production of the assumed prey

\section{A preliminary carbon budget}

The data obtained in this study were used to establish a preliminary carbon budget between bacteria, HNF, ciliates and phytoplankton for the dry and the rainy seasons, respectively (Fig. 8). The data that were used to calculate the magnitude of the different fluxes are presented in Table 5. In this study the fractionated primary production was not measured. However, the average total primary production is similar to the total primary production obtained in diel experiments $(105 \mu \mathrm{g} \mathrm{C}$ $\mathrm{l}^{-1} \mathrm{~d}^{-1}$ during a rainy season and $19 \mu \mathrm{g}$ $\mathrm{C}^{-1} \mathrm{~d}^{-1}$ during a dry season; Wallberg \& Andersson unpubl.) when fractionated primary production was measured. From the diel experiments the percentage distribution between the size classes was used to get an estimate of the production of cyanobacteria (10 and $50 \%$ during the rainy and dry seasons, respectively), nanophytoplankton (30 and $40 \%$ during the rainy and dry seasons, respectively), and phytoplankton $>10 \mu \mathrm{m} \quad 60$ and $10 \%$ during the rainy and dry seasons, respectively).

The production of heterotrophic bacteria amounted to approximately $10 \%$ of the primary production. This suggests that the bacterial production could have phytoplankton as the only source for DOC (Ducklow \& Carlson 1992). The production of heterotrophic bacteria and cyanobacteria balances the HNF carbon demand better during the dry seasons than estimates from the rainy seasons. It is possible that the estimates of the diel production of heterotrophic bacteria are underesti- 
Table 5. Summary of data for the flow of carbon within the microbial food web during the rainy and dry seasons studied. The values for the bacterial and the primary net production are the average values measured during the seasons. The net production of HNF and ciliates was calculated by using the averages of the estimated specific growth rates obtained for each season. The gross growth efficiency was assumed to be $30 \%$ for protozoa and $50 \%$ for bacteria

\begin{tabular}{|c|c|c|c|c|c|c|c|c|}
\hline \multirow[t]{2}{*}{ Taxon } & \multicolumn{2}{|c|}{$\begin{array}{l}\text { Standing stock } \\
\qquad\left(\mu \mathrm{g} \mathrm{Cl}^{-1}\right)\end{array}$} & \multicolumn{2}{|c|}{$\begin{array}{l}\text { Specific growth rate } \\
\qquad\left(\mathrm{d}^{-1}\right)\end{array}$} & \multicolumn{2}{|c|}{$\begin{array}{l}\text { Net production } \\
\left(\mu \mathrm{g} C \mathrm{~d}^{-1} \mathrm{~d}^{-1}\right)\end{array}$} & \multicolumn{2}{|c|}{$\begin{array}{l}\text { Carbon consumption } \\
\left(\mu g \mathrm{C}^{-1} \mathrm{~d}^{-1}\right)\end{array}$} \\
\hline & Dry & Rainy & Dry & Rainy & Dry & Rainy & Dry & Rainy \\
\hline \multicolumn{9}{|l|}{ Autotrophic } \\
\hline Cyanobacteria & $7 \pm 5$ & $6 \pm 3$ & & & 11 & 12 & & \\
\hline Nanoplankton & & & & & 8 & 36 & & \\
\hline Microplankton & & & & & 2 & 72 & & \\
\hline Total & & & & & $21 \pm 15$ & $120 \pm 73$ & & \\
\hline \multicolumn{9}{|l|}{ Heterotrophic } \\
\hline Bacteria & $17 \pm 6$ & $40 \pm 41$ & & & $2 \pm 2$ & $14 \pm 19$ & 4 & 28 \\
\hline Nanoflagellates & $12 \pm 6$ & $9 \pm 5$ & 0.3 & 1.2 & 3.6 & 10.8 & 12 & 36 \\
\hline Microplankton & $4 \pm 2$ & $5 \pm 2$ & 0.9 & 0.9 & 3.6 & 4.5 & 12 & 15 \\
\hline
\end{tabular}

mated as the production was extrapolated over $24 \mathrm{~h}$. As the primary production and, hence, the production of phytoplankton exudates increase during the day, the bacterial production is likely to show a diel variation (Hagström et al. 1988, Wallberg \& Andersson unpubl.). Higher primary production during the rainy (Hama \& Handa 1994, Wallberg \& Andersson unpubl.) as compared to the dry seasons would also give more exudates, with the potential to support higher bacterial production rates. In line with this, results from experiments conducted in the same area suggest that the diel variation in bacterial production is higher during the rainy than the dry season (Wallberg \& Andersson unpubl.).

Even though the bacterial diel production may be underestimated, the carbon budget implies that a significant part of the carbon demand by HNF might be supported by the picocyanobacteria. This uptake route could be particularly important during the dry seasons, when as much as $92 \%$ of the HNF carbon demand potentially could be met by cyanobacteria. The corresponding value for the rainy seasons was $33 \%$. Although the production of cyanobacteria was not directly measured and may be overestimated, the importance of cyanobacteria as a carbon source for HNF is supported by the relatively high correlation between the abundance of cyanobacteria and HNF. Similarly, Hagström et al. (1988) estimated that $57 \%$ of HNF carbon demand was met by cyanobacteria in the Mediterranean Sea. Also, in the Arabian Sea Reckermann \& Veldhuis (1997) estimated that HNF could satisfy their carbon demand exclusively from picophytoplankton.

The carbon budget suggests that 30 to $100 \%$ of the nanoflagellate fraction was consumed by ciliates, with the lowest percentage estimated for the rainy season.
However, it is unlikely that food sources would be idle assets in an oligotrophic environment. Due to the methodological problems described above, the ciliate production may have been underestimated. In addition to ciliates, heterotrophic dinoflagellates may also feed on nanoflagellates. The relative significance of these 2 protist groups as predators on nanoflagellates is still unclear but laboratory data suggest that dinoflagellates ingest prey that correspond to their own size most efficiently (Hansen 1992).

In summary, the results from this study indicate that the heterotrophic microorganisms increased their growth rate during the rainy season without major changes in biomass. The hypothesis that the bacterial production balances the carbon demand by HNF suggests that the carbon flow from heterotrophic and autotrophic bacteria via HNF to ciliates was approximately 3 times higher during the rainy season compared to the dry season. In this context it is interesting to note that when the average of all ciliate growth rates (not only the positive growth rates) was calculated, the growth rate for the rainy season was 3 times higher than the average value for the dry season. However, in spite of a higher efficiency in the carbon flow during the rainy season, heterotrophic microplankton may have been more important as a carbon source for higher trophic levels during the dry season due to the relatively lower production of larger phytoplankton.

Acknowledgements. This work was supported by grants from the Swedish International Development Cooperation/Department for Research Cooperation (SIDA/SAREC). We thank Anders Sjösten for the nutrient analyses and help with the POC and DOC analysis, the boatmen at the Institute of Marine Sciences, Zanzibar, for assistance during sampling, and the Directorate of Meteorology, Zanzibar, for the rainfall data. The use of laboratory facilities at the Institute of Marine Sciences, Zanzibar, is gratefully acknowledged. 


\section{LITERATURE CITED}

Andersen $\mathrm{P}$, Fenchel $\mathrm{T}$ (1985) Bacterivory by microheterotrophic flagellates in seawater samples. Limnol Oceanogr 30:198-202

Andersen P, Sørensen HM (1986) Population dynamics and trophic coupling in pelagic microorganisms in eutrophic coastal waters. Mar Ecol Prog Ser 33:99-109

Cho BC, Azam F (1990) Biogeochemical significance of bacterial biomass in the ocean's euphotic zone. Mar Ecol Prog Ser 63:253-259

Cushing DH (1989) A difference in structure between ecosystems in strongly stratified waters and in those that are only weakly stratified. J Plankton Res 11:1-13

Ducklow HW, Carlson CA (1992) Oceanic bacterial production. Adv Microb Ecol 12:113-181

Fenchel T (1968) The ecology of marine microbenthos. III The reproductive potential of ciliates. Ophelia 5:123-136

Fenchel I (1982) Ecology of heterotrophic microflagellates. IV Quantitative occurrence and importance as bacterial consumers. Mar Ecol Prog Ser 9:35-42

Fenchel T, Finlay BJ (1983) Respiration rates in heterotrophic free-living protozoa. Microb Ecol 9:99-122

Finlay BJ (1977) The dependence of reproductive rate on cell size and temperature in freshwater ciliated protozoa. Oecologia (Berl) 30:75-81

Fuhrman JA, Sleeter TD, Carlson CA, Proctor LM (1989) Dominance of bacterial biomass in the Sargasso Sea and its ecological implications. Mar Ecol Prog Ser 57:207-217

Gallegos CL, Jordan TE, Correll DL (1992) Event-scale response of phytoplankton to watershed inputs in a subestuary: timing, magnitude, and location of blooms. Limnol Oceanogr 37:813-828

Gasol JM (1994) A frame work for assessment of top-down vs bottom-up control of heterotrophic nanoflagellate abundance. Mar Ecol Prog Ser 113:291-300

Gilron GL, Lynn DH (1989) Estimates of in situ population growth rates of four tintinnine ciliate species near Kinstone Harbour, Jamaica. Estuar Coast Shelf Sci 29:1-10

Haas LW (1982) Improved epifluorescence microscopy for observing planktonic micro-organisms. Ann Inst Oceanogr 58(Suppl):261-266

Hagström $\AA$, Azam $F$, Andersson A, Wikner J, Rassoulzadegan $F$ (1988) Microbial loop in an oligotrophic pelagic marine ecosystem: possible roles of cyanobacteria and nanoflagellates in the organic fluxes. Mar Ecol Prog Ser 49:171-178

Hama J, Handa N (1994) Variability of the biomass, chemical composition and productivity of phytoplankton in Kiru-ura bay, Japan during the rainy season. Estuar Coastal Shelf Sci 39:497-509

Hansen PJ (1992) Prey size selection, feeding rates and growth dynamics of heterotrophic dinoflagellates with special emphasis on Gyrodinium spirale. Mar Biol 114: $327-334$

Jonsson PR, Tiselius P (1990) Feeding behaviour, prey detection and capture efficiency of the copepod Acartia tonsa feeding on planktonic ciliates. Mar Ecol Prog Ser 60 35-44

Kiørboe T, Kaas H, Kruse B, Mohlenberg F, Tiselius P, Aertebjerg $G$ (1990) The structure of the pelagic food web in relation to water column structure in the Skagerrak. Mar Ecol Prog Ser 59:19-32

Kirchman DL, Ducklow HW (1993) Estimating conversion factors for the thymidine and leucine methods for measuring bacterial production. In: Kemp PF, Sherr BF, Sherr EB, Cole JJ (eds) Handbook of methods in aquatic microbial ecology. Lewis Publishers, London, p 513-517
Legendre L, Rassoulzâdegan F (1995) Plankton and nutrient dynamics in marine waters. Ophelia 41:153-172

Li WKW, Subba Rao DV, Harrison WG, Smith JC, Cullen JJ, Irwin B, Platt T (1983) Autotrophic picoplankton in the tropical ocean. Science 219:292-295

Lugomela CV, Semesi AK (1996) Spatial and temporal variations in phytoplankton in Zanzibar near shore waters. In: Björk M, Semesi AK, Pedersén M, Bergman B (eds) Current trends in marine botanical research in the East. Africa region. SIDA/Department for Research Cooperation, Stockholm, p 235-251

Marshall SM (1969) Protozoa order: Tintinnida. Fich Ident Zooplancton, Charlottenlund, p 117-124

Montagnes DJS (1996) Growth responses of planktonic ciliates in the genera Strobilidium and Strombidium. Mar Ecol Prog Ser 130:241-254

Montagnes DJS, Lynn DH (1991) Taxonomy of Choreotrichs, the major marine planktonic ciliates, with emphasis on the aloricate forms. Mar Microb Food Webs 5:59-74

Müller H, Geller W (1993) Maximum growth rates and aquatic ciliated protozoa: the dependence on body size and temperature reconsidered. Arch Hydrobiol 126: $315-327$

Nielsen TG, Kiørboe T (1991) Effects of a storm event on the structure of the pelagic food web with special emphasis on planktonic ciliates. J Plankton Res 13:35-51

Parsons R, Maita Y, Lalli CM (1989) A manual of chemical and biological methods for seawater analysis. Pergamon Press, Oxford, p 14-17, 141-149

Pengerud B, Skjoldal EF, Thingstad TF (1987) The reciprocal interaction between degradation of glucose and ecosystem structure. Studies in mixed chemostat cultures of marine bacteria, algae, and bacterivorous nanoflagellates. Mar Ecol Prog Ser 35:111-117

Pierce RW, Turner JT (1992) Ecology of planktonic ciliates in marine food webs. Rev Aquat Sci 6:139-181

Porter KG, Feig Y (1980) The use of DAPI for identifying and counting aquatic microflora. Limnol Oceanogr 25: 943-948

Putt M. Stoecker DK (1989) An experimentally determined carbon-volume ratio for marine oligotrichous ciliates from estuarine and coastal waters. Limnol Oceanogr 34: $1097-1103$

Reckermann M, Veldhuis MJW (1997) Trophic interactions between picophytoplankton and micro- and nanozooplankton in the western Arabian Sea during the NE monsoon 1993. Aquat Microb Ecol 12:263-273

Roman MR, Caron DA, Kremer P, Lessard EJ, Madin LP, Malone TC, Napp JM, Peele ER, Youngbluth MJ (1995) Spatial and temporal changes in the partitioning of organic carbon in the plankton community of the Sargasso Sea off Bermuda. Deep-Sea Res 42:973-992

Sanders RW, Caron, DA, Berninger UG (1992) Relationship between bacteria and heterotrophic nanoplankton in marine and fresh waters: an inter-ecosystem comparison. Mar Ecol Prog Ser 86:1-14

Sherr BF, Sherr EB, Pedrós-Alió C (1989) Simultaneous measurement of bacterioplankton production and protozoan bacterivory in estuarine water. Mar Ecol Prog Ser 54: 209-219

Simon M, Azam F (1989) Protein content and protein synthesis rates of planktonic marine bacteria. Mar Ecol Prog Ser 51:201-213

Smith DC, Azam F (1992) A simple economical method for measuring bacterial protein synthesis rates in seawater using ${ }^{3} \mathrm{H}$-leucine. Mar Microb Food Webs 6:107-114

Sorokin YI (1981) Microheterotrophic organisms in marine 
ecosystems. In: Longhurst AR (ed) Analysis of marine ecosystems. Academic Press, London, p 293-342

Stoecker DK, Taniguchi A, Michaels AE (1989) Abundance of autotrophic, mixotrophic and heterotrophic planktonic ciliates in shelf and slope waters. Mar Ecol Prog Ser 50: $241-254$

Stoecker DK, Gustafson DE, Verity PG (1996) Micro- and mesoprotozooplankton at $140^{\circ} \mathrm{W}$ in the equatorial Pacific: heterotrophs and mixotrophs. Aquat Microb Ecol 10: $273-282$

Tiselius P (1989) Contribution of aloricate ciliates to the diet of Acartia clausi and Centropages hamatus in coastal waters. Mar Ecol Prog Ser 56:49-56

Torréton JP, Guiral D, Arfi R (1989) Bacterioplankton biomass

Editorial responsibility: Tom Fenchel,

Helsingor, Denmark and production during destratification in a monomictic eutrophic bay of a tropical lagoon. Mar Ecol Prog Ser 57: $53-67$

Verity PG (1985) Grazing, respiration, excretion, and growth rates of tintinnids. Limnol Oceanogr 30:1268-1282

Verity PG, Robertson CY, Tonzo CR, Andrews MG, Nelson JR, Sieracki ME (1992) Relationships between cell volume and the carbon and nitrogen content of marine photosynthetic nanoplankton. Limnol Oceanogr 37:1434-1446

Waterbury JB, Watson SW, Guillard RRL, Brand LE (1979) Widespread occurrence of a unicellular, marine planktonic, cyanobacterium. Nature 227:293-294

Winer BJ, Brown DR, Michels KM (1991) Statistical principles in experimental design. McGraw-Hill, New York

Submitted: February 26, 1998; Accepted: December 21, 1998 Proofs received from author(s): July 19, 1999 